\section{Voluntary counseling and testing (VCT) services and their contribution to access to HIV diagnosis in Brazil}

\author{
Contribuição dos Centros de Testagem e \\ Aconselhamento (CTA) para o acesso \\ ao diagnóstico da infecção pelo \\ HIV no Brasil
}

\author{
Alexandre Grangeiro ${ }^{1}$ \\ Maria Mercedes Escuder 2 \\ Maria Amélia Veras 3 \\ Draurio Barreira 4 \\ Dulce Ferraz 5 \\ Jorge Kayano 2
}

\footnotetext{
${ }^{1}$ Faculdade de Medicina, Universidade de São Paulo, São Paulo, Brasil.

2 Instituto de Saúde, São Paulo, Brasil.

3 Faculdade de Ciências Médicas da Santa Casa São Paulo, Brasil.

4 Programa Nacional de Controle da Tuberculose, Ministério da Saúde, Brasília, Brasil.

5 Programa Nacional de DST e AIDS, Ministério da Saúde, Brasília, Brasil.
}

Correspondence A. Grangeiro Departamento de Medicina Preventiva, Faculdade de Medicina, Universidade de São Paulo.

Av. Dr. Arnaldo 455, $2^{\circ}$ andar, São Paulo, SP 01246-903, Brasil. ale.grangeiro@gmail.com

\begin{abstract}
The Voluntary Counseling and Testing (VCT) Network was implemented in Brazil in the $1980 \mathrm{~s}$ to promote anonymous and confidential access to HIV diagnosis. As a function of the population and dimensions of the local epidemic, the study assessed the network's coverage, using data from a self-applied questionnaire and data from the Information Technology Department of the Unified National Health System (SUS), UNDP, and National STD/AIDS Program. The Student t test was used for comparison of means and the chi-square test for proportions. Brazil has 383 VCT centers, covering $48.9 \%$ of the population and $69.2 \%$ of the AIDS cases. The network has been implemented predominantly in regions where the epidemic shows a relevant presence, but $85.3 \%$ of the cities with high HIV incidence lack VCT centers; absence of VCT was associated with more limited health infrastructure and worse social indicators. A slowdown in expansion of the network was observed, with VCT Centers implemented on average 16 years after the first AIDS case in the given municipality. The number of HIV tests performed under the SUS is 2.3 times higher in cities with VCT centers. The network's scope is limited, thus minimizing the contribution by these services to the supply of HIV diagnosis in Brazil.
\end{abstract}

Anonymous Testing; Acquired Immunodeficiency Syndrome; Health Services Evaluation

\section{Introduction}

The World Health Organization (WHO) and the Joint United Nations Program on HIV/AIDS (UNAIDS) have defined early diagnosis of HIV infection as one of the priorities for controlling the AIDS epidemic worldwide. According to analyses by these agencies published in 2004 , only $0.2 \%$ of adults in low and medium-income countries had been tested for HIV and received counseling, and $90 \%$ of the individuals that need an HIV test (based on exposure to risk) lack access to specialized services 1 .

In Brazil, HIV testing began in 1985, the same year that the U.S. Food and Drug Administration (FDA) registered the first diagnostic kits 2 . Since then, $28.1 \%$ of the Brazilian adult population from 15 to 54 years of age has received an HIV test 3 , a rate equivalent to that observed in other medium and low-income countries like South Africa and India, and lower than in other countries that have adopted comprehensive strategies to promote the diagnosis, like Cuba, Thailand, and the United States 4.

The proportion of individuals that have tested for HIV infection in Brazil is higher among women $(35 \%)$, individuals with complete primary schooling or more $(38.5 \%)$, and residents of regions with better socioeconomic indicators and health services $(34.9 \%) 3$, while the proportion of individuals that go take the HIV test to clarify a risk situation is low (9.2\%) 5 . 
As a way of expanding the supply of HIV diagnosis to populations and regions with higher HIV incidence, Brazil began implementation of a national network of Voluntary Counseling and Testing (VCT) Centers in 1988. These centers were organized to promote accessibility, gratuity, voluntariness, confidentiality, anonymity, and agility in supplying HIV testing, while recommending that counseling and diagnosis be performed effectively and in collaboration with the other health services for referral of the diagnosed cases 6 .

Furthermore, these testing and counseling services were to be implemented under the management of State and Municipal health departments in easily accessible sites with high HIV incidence, offering serological testing and preventive measures for the entire population, prioritizing those segments identified as having increased risk of infection, that experience difficulty in accessing conventional health facilities, and/or that rely on blood banks for HIV testing 6 .

Twenty years after the implementation of the first VCT center in Brazil, various studies using distinct methodologies have analyzed the innovative nature of these services, especially: presence of multidisciplinary teams; emphasis on health education practices; adequacy of the work process for meeting the needs of the target populations; inclusion of more vulnerable populations; and the possibility of using the information produced in the services for monitoring trends of the epidemic in the country 6,7,8,9,10.

However, other studies highlight the limitations of these services, emphasizing, among other aspects, that a major share of preventive activities fail to include community interventions and are limited to counseling in conjunction with diagnosis. Such studies have also identified difficulties in linking into the health care network as a whole, deficiencies in referral and counterreferral, and low productivity, with few HIV tests performed in relation to the installed capacity $11,12,13$.

Nonetheless, the studies performed up to the moment do not include all of the VCT centers implemented in Brazil, raising difficulties to diagnose more precisely the contribution of these services in the development of AIDS prevention and control activities in the country.

Thus, the Ministry of Health requested a study on the existing circumstances of the VCT centers, focusing on acknowledgment of the structure, organization, and scope of these services.

This article analyzes the coverage of testing and counseling services in relation to the Brazilian population, the epidemic's dimensions, and the number of HIV tests performed under the
Unified National Health System (SUS). The findings serve as basis for discussing the capacity of these services to contribute to the promotion of universal coverage and equity of access to HIV diagnosis by the Brazilian population. A study will also be presented on the services' geographic distribution in relation to the regions of Brazil with the highest AIDS incidence.

\section{Methodology}

The study of the national VCT network, called the Situational Diagnosis of Counseling and Testing Centers in Brazil, includes the entirety of these services in the country's 26 States and the Federal District. The services were identified through a Ministry of Health registry, which was updated by means of telephone inquiries to the State health departments and the centers themselves. VCT services were defined as those that adopted that name themselves or were referred to as such by States' the health departments or the Ministry of Health.

The data were collected from August 2006 to January 2007, using a structured questionnaire sent by mail and completed by the VCT administrators or health professionals working at the services and designated by them. For this study's purposes, information was used on the number of HIV tests (ELISA, or enzyme-linked immunosorbent assay) conducted in the year 2005; the HIV-positive rate for the service's clientele; municipality of the service installed; year of initial operations; and inclusion of the VCT center's structure in other health units. The VCT centers that failed to answer the questionnaire $(63$, or $16.4 \%$ of all the services) had the information on the last three variables collected by means of telephone contact.

The data obtained directly from the VCT centers were complemented by information on trends of the epidemic (National STD/AIDS Program. AIDS Data in Brazil [Internet database]. http://www.aids.gov.br/final/dados_aids.asp, accessed on 18/Jun/2007; National STD/AIDS Program. Incentive Policy [database on Microsoft Excel spreadsheet]), the health system's structure (Information Technology Department of the Unified National Health System.http://w3.datasus. gov.br/datasus / datasus.php?area=359A1B0C0D 0E0F359G1HIJd1L2M0N\&VInclude=/site/texto. php, accessed on 18/Jun/2007; Information Sys tem on Public Health Budgets, http://siops.data sus.gov.br/indicamun.php?escmun=3, accessed on $18 / \mathrm{Jun} / 2008$ ), and the socio-demographic characteristics 14 of the municipalities (counties) with and without VCT centers. Data were col- 
lected for the year 2005, using the population 13 years and older as the reference whenever pertinent and available, except for the data on the Incentive Policy, which refer to 2006, the socio-demographic data, which are from the 2000 census, and the epidemiological data, from 1990 to 2005.

Evaluation of the VCT network was organized in four dimensions. The first dimension attempted to characterize the network's coverage by estimating: (1) the proportions of AIDS cases and residents in municipalities with VCT centers, in relation to the total number of cases and the country's total population; (2) number of VCT centers per million inhabitants; and (3) number of HIV tests performed under the Unified National Health System (SUS) per thousand inhabitants. The population and AIDS indicators were analyzed over time, with the objective of studying the gradual development of the VCT centers' coverage over the course of 15 years.

The second dimension analyzed the synergy between the geographic distribution of the AIDS epidemic and the VCT network, with the aim of observing whether the services were implemented where the epidemic was actually a public health problem. The unit of analysis was municipalities that have VCT services implemented, which were categorized according to their incidence rates: municipalities with $\geq 25$ AIDS per 100 thousand inhabitants were classified as having high incidence, from 10 to 24.9 AIDS cases per 100 thousand inhabitants as medium incidence, and those with $\leq 9.9$ AIDS cases per 100 thousand inhabitants as low incidence. Municipalities without AIDS were included in a specific group.

The third dimension aimed to evaluate whether the municipalities considered priorities for AIDS prevention and control were covered by the national VCT network, adopting as the unit of analysis the set of cities with medium or high incidence and the municipalities included in the Federal Incentive Policy.

The fourth analytical dimension aimed to identify factors associated with the presence or absence of VCT centers in given cities. This study adopted the set of municipalities with medium or high AIDS incidence, comparing epidemiological, socio-demographic, and health system indicators for groups of municipalities with and withoutVCT services. The analyzed indicators related to: (1) AIDS epidemic: incidence and time since onset of the epidemic in the municipality; (2) response to AIDS: proportion of resources from the Federal Incentive Policy for AIDS treatment applied to prevention and care and number of HIV tests performed per thousand inhabitants; (3) economic and social: per capita GDP, HDI-M (Municipal Human Development Index), and life expectancy at birth; (4) health system: public expenditures on health, coverage of primary care services and number of physicians, medical consultations, and outpatient procedures per inhabitant.

Comparison of municipal indicators was based on tests related to the nature of the variables, i.e., means were compared with the Student $t$ test, and the chi-square test was used for proportions, with a significance level of 0.05.

The information used to construct the indicators, according to the sources, included: (1) the Brazilian National STD/AIDS Program (Programa Nacional de DST and AIDS. Dados de AIDS no Brasil [Internet database]. http://www.aids. gov.br/final/dados_aids.asp, accessed on 18/ Jun/2007; Programa Nacional de DST e AIDS. Política de incentivo [Microsoft Excel spreadsheet database]) - number of new AIDS cases, date of first reported case of the disease in the municipality and the amount of funds planned within the Federal Incentive Policy by area of activity; (2) Information Technology Department of the Unified National Health System (DATASUS. Informações de saúde. http://w3.datasus.gov. $\mathrm{br} /$ datasus $/$ datasus.php? area=359A1B0C0D0E0 F359G1HIJd1L2M0N\&VInclude=/site/texto.php, accessed on 18/Jun/2007) and the Information System on Public Health Budgets (SIOPS. http:// siops.datasus.gov.br/indicamun.php?escmun=3, accessed on 18/Jun/2008) - number of HIV tests (ELISA) billed in the National Health System (SUS) and primary and non-primary outpatient production, coverage of the Family Health Program (FHP), STD treatment at the primary care level, number of physicians per thousand inhabitants, medical consultations per inhabitant, health expenditures and percentage of the municipal budget allocated for health; and (3) United Nations Development Program (UNDP) 14 - HDI-M, GINI, per capita GDP, life expectancy at birth, and infant mortality.

\section{Results}

A total of 383 VCT services were identified, corresponding to 2.3 services per million inhabitants (Table 1). The years 1996, 2001, and 2003 had the largest number of services implemented (127), representing $33.1 \%$ of all the VCT services in Brazil (Figure 1). The VCT services are mostly under municipal management $(87.2 \%)$, included in specialized AIDS care units (40.9\%), or part of primary care services $(21.6 \%)$ (Table 1$)$.

As a whole, the national VCT network accounted for 630,046 HIV tests in the year 2005, considering the 282 services that provided this 
Characteristics of the national network of Voluntary counseling and Testing (VCT) centers. Brazil, 2005

\begin{tabular}{|c|c|}
\hline Network characteristics & Values \\
\hline Number of VCT services & 383 \\
\hline Number of VCT services per million inhabitants & 2.3 \\
\hline Number of municipalities with VCT services & 285 \\
\hline Number of tests performed by VCT services * & 630,046 \\
\hline \multicolumn{2}{|l|}{ Management level } \\
\hline Percentage under Municipal management & 87.2 \\
\hline Percentage under State management & 12.8 \\
\hline \multicolumn{2}{|l|}{ Position in the health network } \\
\hline $\begin{array}{l}\text { Percentage of VCT services included in AIDS programs or with an autonomous } \\
\text { physical/administrative structure in relation to the general health care network }\end{array}$ & 18.1 \\
\hline Percentage of VCT services included within primary care services & 21.6 \\
\hline Percentage of VCT services included within the specialized AIDS care network & 40.9 \\
\hline Percentage of VCT services included within the secondary care (except AIDS) network & 19.4 \\
\hline \multicolumn{2}{|l|}{ Size of services } \\
\hline Percentage with low throughput ( $\leq 5$ HIV tests/day) & 40.8 \\
\hline Percentage with medium throughput ( 6 to $15 \mathrm{HIV}$ tests/day) & 41.1 \\
\hline Percentage with high throughput (> 15 HIV tests/day) & 18.1 \\
\hline \multicolumn{2}{|l|}{ Percentage of positive HIV tests in the clientele } \\
\hline $0 \%+1 \%$ & 36.9 \\
\hline $1 \%+5 \%$ & 50.4 \\
\hline$\geq 5 \%$ & 12.7 \\
\hline \multicolumn{2}{|l|}{ AIDS incidence per 100,000 inhabitants } \\
\hline Municipalities with VCT services & 25.0 \\
\hline Municipalities without VCT services & 17.5 \\
\hline \multicolumn{2}{|l|}{ HIV ELISA tests performed under the Unified National Health System (2006) } \\
\hline Total, Brazil & $4,444,364$ \\
\hline Number of tests per 1,000 inhabitants - Brazil & 23.8 \\
\hline Number of tests per 1,000 inhabitants - municipalities with VCT services & 43.7 \\
\hline Number of tests per 1,000 inhabitants - municipalities without VCT services & 18.6 \\
\hline
\end{tabular}

* Information for 282 VCT services.

information. Of these, $81.9 \%$ performed up to 15 HIV tests per day and were classified as medium or small services. The proportion of positive tests varied from $0.05 \%$ to $20.8 \%$, excluding ten services that did not report any positive tests. Nearly two-thirds of the services $(63.1 \%)$ reported an HIV-positive rate equal to or greater than $1 \%$, higher than that of the overall Brazilian population from 15 to 49 years of age, which is $0.6 \%$ (Table 1).

In the year 2006, a total of 4,444,364 HIV tests were performed under the Unified National Health System, corresponding to 23.8 tests per thousand inhabitants. In municipalities with
VCT services, this figure was 2.3 greater than in municipalities without such services (43.7 and 18.6 tests/thousand inhabitants, respectively) (Table 1).

The national VCT network covers 285 Brazilian municipalities, which corresponds to $48.8 \%$ of the Brazilian population and $69.2 \%$ of the AIDS cases. These proportions showed a positive variation from 1990 to 2005, with an incre ase of 1.4 and 3.2 times for the population and the number of AIDS cases, respectively (Table 1 and Figure 2).

Since 1998, there has been a decrease in the growth of coverage rates. This slowdown is as- 
Figura 1

Number of Voluntary Counseling and Testing (VCT) centers and year of implementation. Brazil, 2005.

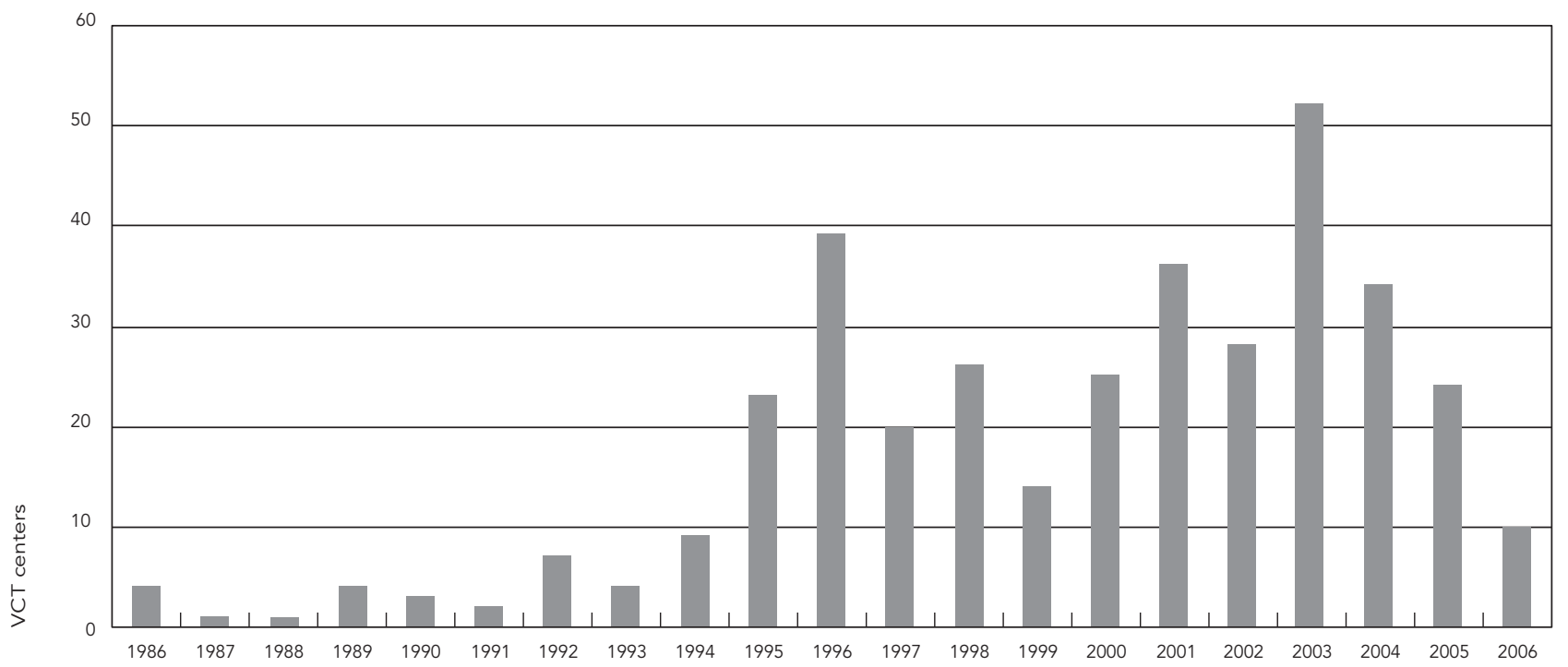

Figura 2

Population coverage of Voluntary Counseling and Testing (VCT) centers, AIDS cases, and time between diagnosis of first AIDS case and implementation of VCT in the municipality. Brazil, 1990-2005.

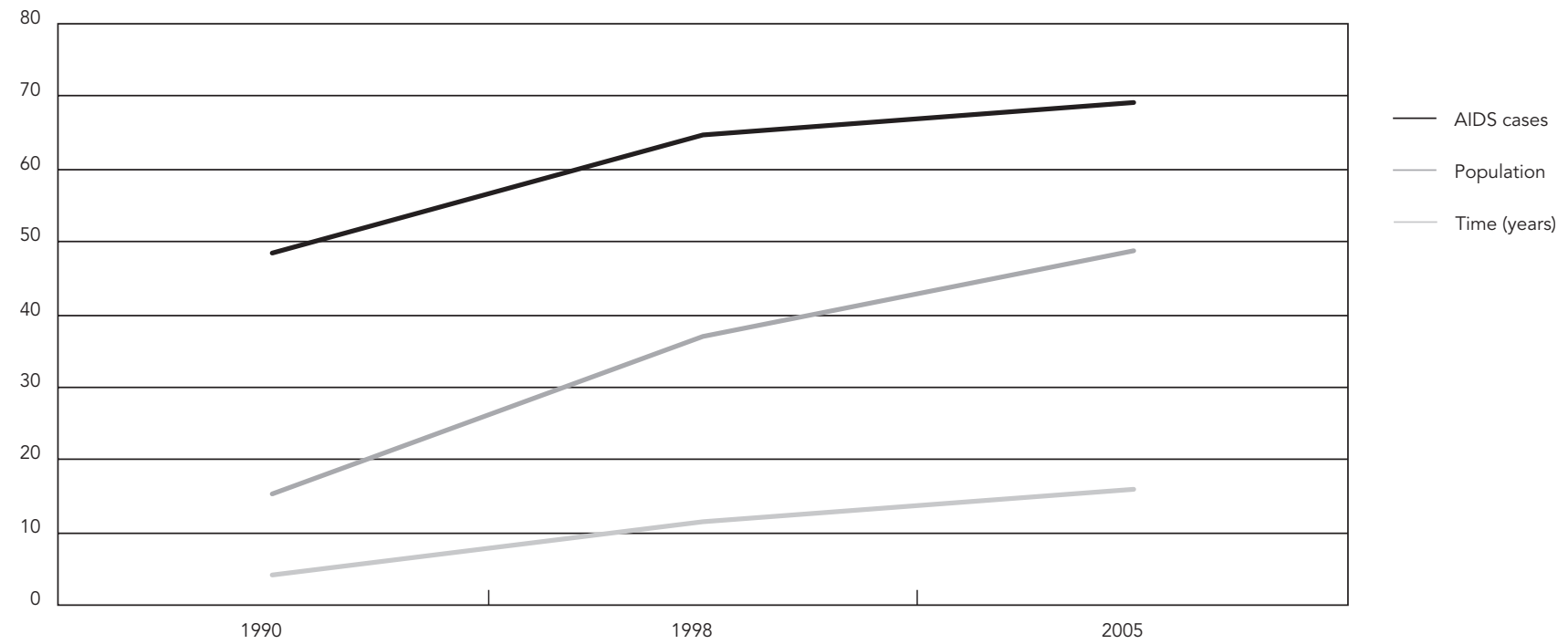


sociated with the expansion of the VCT network, predominantly in cities with smaller populations and a lower concentration of AIDS cases. Importantly, $54.5 \%$ of the services have been implemented since 2000 (Figure 1), and 67.9\% of these were in cities with up to 200 thousand inhabitants.

In this context, it is important to emphasize the systematic increase in the time lag between the appearance of the first AIDS case and the implementation of the first VCT service in the respective municipality. In 2005, on average, this lag was 16 years, four times longer than in 1990 (Figure 2). Thus, although an important share of the VCT services have been implemented since 2000, the national VCT network is characterized as being located in municipalities where the epidemic is older, as shown by the high percentage (97.1\%) of cities with VCT services that reported their first AIDS case before 1995 (Table 2).

The VCT network, considering the 383 existing services, is implemented mainly in municipalities with medium or high AIDS incidence rates ( $84 \%$ of the units) (Figure 3 ), considering that the majority of the VCT services $(70.8 \%)$ are located in cities with incidence rates higher than the national rate for 2005 (18.2 AIDS cases per 100 thousand inhabitants). The incidence rate in cities with VCT services is 1.4 higher than in cities without such services (Table 1), although ten

Table 2

Characteristics of municipalities with medium or high AIDS incidence ( $\geq 10$ cases per 100,000 inhabitants), according to presence of VCT centers. Brazil, 2005

\begin{tabular}{|c|c|c|c|}
\hline \multirow[t]{2}{*}{ Municipal indicators } & \multicolumn{2}{|c|}{ VCT } & \multirow[t]{2}{*}{ p-value } \\
\hline & Present & Absent & \\
\hline \multicolumn{4}{|l|}{ Characteristics of municipalities } \\
\hline VCT services in the municipalities & 241 & 1,584 & - \\
\hline Resident population $\geq 13$ years of age & $65,857,586$ & $35,562,123$ & - \\
\hline \multicolumn{4}{|l|}{ AIDS epidemiology } \\
\hline Incidence per 100,000 inhabitants & 28.1 & 26.9 & 0.376 * \\
\hline Percentage of municipalities with first case since 1995 & 2.9 & 41.1 & 0.000 ** \\
\hline \multicolumn{4}{|l|}{ AIDS program } \\
\hline Percentage of funds from Federal Incentive Policy spent on prevention & 35.0 & 37.1 & 0.266 ** \\
\hline Percentage of funds from Federal Incentive Policy spent on treatment & 27.2 & 28.3 & 0.556 ** \\
\hline $\begin{array}{l}\text { Mean number of HIV ELISA tests performed under National Health System } \\
\text { per 1,000 inhabitants }\end{array}$ & 45.4 & 24.0 & 0.000 * \\
\hline \multicolumn{4}{|l|}{ Health System } \\
\hline Mean per capita public expenditure on health $(R \$)[U \$ 1=R \$ 1.8]$ & 205.9 & 197.8 & 0.266 * \\
\hline Health as percentage of municipal budget & 18.8 & 19.0 & $0.385^{\star *}$ \\
\hline Mean coverage of Family Health Program & 41.3 & 68.5 & 0.000 * \\
\hline Mean per capita primary outpatient production & 7.2 & 8.6 & 0.000 * \\
\hline Mean STD/AIDS primary care production per 1,000 inhabitants & 7.4 & 16.5 & 0.440 * \\
\hline Mean non-primary care production per capita & 6.8 & 3.0 & 0.000 * \\
\hline Number of physicians per 1,000 inhabitants & 1.1 & 0.4 & 0.000 * \\
\hline Medical consultations per inhabitant & 1.6 & 1.6 & 0.614 * \\
\hline \multicolumn{4}{|l|}{ Economic and social } \\
\hline Per capita GDP (R\$) [U\$1 = R\$1.8] & $12,429.34$ & $9,220.17$ & $0.017^{*}$ \\
\hline HDI-M & 0.77 & 0.72 & 0.000 * \\
\hline Life expectancy at birth & 69.8 & 69.0 & $0.005^{*}$ \\
\hline Infant mortality per 1,000 live births & 25.8 & 28.9 & 0.001 * \\
\hline GINI Index & 0.58 & 0.55 & 0.000 * \\
\hline
\end{tabular}

* Student $t$ test;

${ }^{\star *}$ Chi-squared. 
3a) Municipalities with VCT services according to AIDS incidence bracket

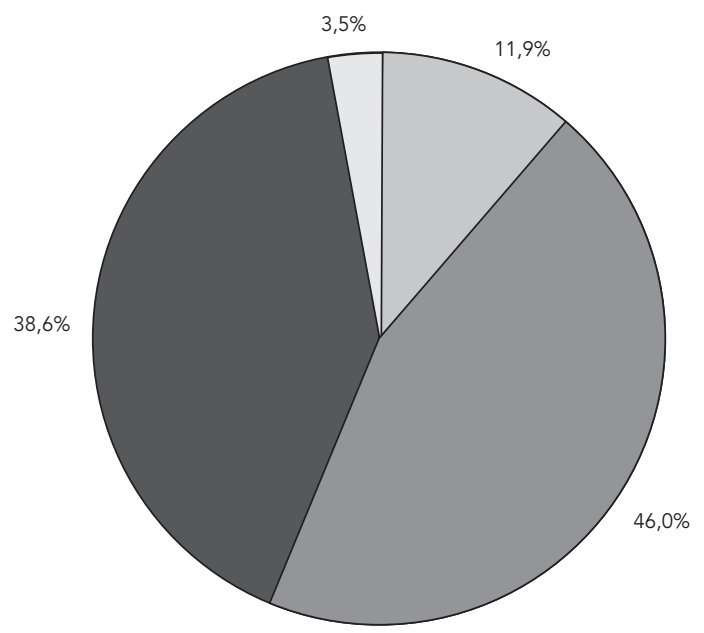

$$
\begin{aligned}
& \bigsqcup \text { Without AIDS } \\
& \square \text { Low ( } \leq 9.9 / 100,000 \text { inhabitants) } \\
& \square \text { Medium (10.0-24.9/100,000 inhabitants) } \\
& \text { High (25.0/100,000 inhabitants) }
\end{aligned}
$$

3b) Municipalities with high HIV incidence according to presence of VCT services

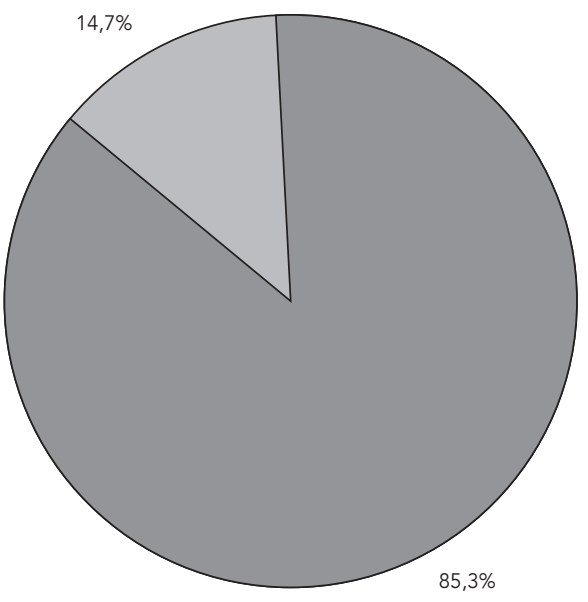

$$
\begin{aligned}
& \square \text { Without VCT services } \\
& \square \text { With VCT services }
\end{aligned}
$$

cities (4\%) that provide the service did not report AIDS cases in 2005.

VCT services are lacking in nearly half $(48.9 \%)$ of the municipalities classified by the Ministry of Health as priorities for AIDS control and that receive Federal funds to conduct related activities under the Federal Incentive Policy. The same is true for $85.3 \%$ of the cities with 25 AIDS cases or more per 100 thousand inhabitants, classified in this study as having high incidence (Figure 3).
The absence of VCT services in $86.8 \%$ of the 1,584 municipalities classified as having high or medium AIDS incidence (Table 2) may be related to the health care model, which is characterized in these municipalities by higher Family Health Program coverage and more primary care consultations per inhabitant. These municipalities also display a more recent HIV/AIDS epidemic, considering that $41.1 \%$ of them reported their first AIDS cases after 1995. 
Meanwhile, in the municipalities with VCT services, the health care model is characterized by having more physicians and more non-primary procedures per inhabitant (which includes medium and high-complexity procedures). The municipalities in this group have larger populations and proportionally better social indicators, such as higher life expectancy at birth, lower social inequality, better HDI-M, and lower infant mortality, as compared to the municipalities without VCT services, but with the same AIDS incidence rates (Table 2).

Health expenditures, mean AIDS incidence rate, number of primary care procedures in STD/ AIDS, number of medical consultations per inhabitant, and the proportion of funds from the Federal Incentive Policy invested in care and prevention did not help differentiate between municipalities with and without VCT services, so no association was identified for any group with the municipalities that were analyzed (Table 2).

Importantly, 67 of the 285 municipalities with VCT services (23.5\%) are not among those classified by the Ministry of Health as priorities and that receive Federal funds to conduct program activities. These municipalities (data not shown in table form) show lower AIDS incidence rates than the other priority municipalities, are located in regions where the epidemic is more recent $(59.7 \%$ of the services are in the North and Northeast), and have the worst social and health indicators of all the municipalities with VCT services, with a per capita GDP of R\$8.2 thousand (approximately U $\$ 4,500 /$ year), HDI-M of 0.71 , infant mortality rate of 34.8 per thousand live births, and low number of medical consultations per inhabitant (1.3).

\section{Discussion}

The Brazilian national VCT network is implemented in regions with high or medium AIDS incidence, covering municipalities with an important share of the country's AIDS cases and approximately half of the national population 13 years or older. The services have been implemented mainly in municipalities where the epidemic is older and which have a health care model characterized by a greater presence of physicians and a supply of secondary care services, with a prevalence of medium and highcomplexity procedures.

However, the network's scope is limited, and the population in a significant number of municipalities with high AIDS incidence and that have been defined as priority areas for control of the disease lacks access to VCT services, thus jeop- ardizing the role of these services in promoting universal access to HIV diagnosis in public health services and consequently reducing the country's capacity to control the epidemic more effectively. The municipalities withoutVCT services perform fewer HIV tests within the sphere of the National Health System and have worse social development and health infrastructure indicators.

The lack of VCT services in these municipalities can have negative implications for the supply of HIV diagnosis to the population. Specialized testing and counseling centers have been assessed as the most adequate services for providing HIV diagnosis with quality 15 , constituting an alternative for overcoming typical barriers to access within health services.

The unavailability of HIV diagnosis in the health system can induce individuals to rely on testing in places or situations that are not recommended by health agencies and which, in specific cases, violate ethical principals and individual rights, such as testing performed at the workplace, in blood banks, or during late pregnancy or childbirth, as demonstrated by various Brazilian studies 3,16 .

The negative consequences of the inadequate supply of HIV testing also entail: precarious or nonexistent counseling 11; reduced efficacy of prophylactic measures against mother-to-child transmission 17,18; antiretroviral treatment initiated in advanced stages of the disease 19; an increase in the number of new infections and deaths from AIDS 20,21; and a probable increase in the risk of HIV transmission through blood transfusions, due to the fact that persons in risk situations turn to blood banks for HIV testing, thus increasing the odds of giving blood during the window period 22 .

It is significant that a relatively low proportion of all the HIV tests performed under the National Health System occur within VCT services. The services' idle capacity and the need to expand the actions they perform have been the object of discussion in the literature 9,11,12,13, based on the observation that the proportion of the Brazilian population that has already had an HIV test 3,5 increased only slightly in recent years.

There is a worrisome lag between the appearance of the first AIDS cases and the implementation of VCT services in a given municipality. Early, anticipatory prevention and control measures in relation to the epidemic have been identified as important factors for obtaining positive results with AIDS 23. This should be considered a strategic aspect in light of the epidemic's growth in small and medium-sized municipalities, which show the worst social and health indicators, as observed in the study. 
This situation can be reversed by health policies that encourage HIV testing. The study's results suggest that the increase in the number of new VCT services, especially in the years 1996, 2001, and 2003, is related to three distinct aspects. For example, the World Bank Loan Agreement implemented from 1994 to 1998 was the principal factor in financing and disseminating VCT services, allowing their implementation in Brazil's main cities 24 . Meanwhile, the year 2001 coincided with the scaling-up of strategies to diagnose and treat infected pregnant women, within the context of preventing mother-to-child transmission. And in 2003, HIV diagnosis was defined as a priority for controlling the disease, as reflected in the strengthening of the laboratory network, with advertising campaigns to encourage testing and the establishment of the Federal Incentive Policy, which has expanded the number of municipalities with specific AIDS programs.

A positive aspect of the VCT services is their capacity to help promote equitable access to HIV diagnosis, as evidenced by the high HIV-positive rate detected by them. This corroborates studies on the epidemiological and socio-demographic profile of VCT users 25,26. Priority care for more vulnerable individuals is related to the services' organization and activities, which minimize stigma and prejudice and facilitate the individual's decision to seek the test 1,27 .

This characteristic of VCT services is relevant to the extent that important proportions of the most vulnerable social groups do not test for HIV, as demonstrated by cross-sectional studies in various regions of Brazil: $72.7 \%$ of homosexuals $5,34.2 \%$ of injecting drug users 28 , and $63.5 \%$ of sex workers not included in prevention programs ${ }^{29}$ have never had an HIV test.

Potential limitations to the study are the fact that part of the information was obtained through the services' own managers and databases, which are known to be deficient in some cases 10 . This may result in less precise information and idealized answers, e.g. concerning the number of tests performed by the services.

Furthermore, despite the effort to include all the services identified as VCT centers, regardless of such characteristics as their position within the health network or time since they began operations, it is important to recall that the definition of VCT services is rather imprecise and may have influenced the number of services included in (or excluded from) the study. At the limit, this includes health services that offer testing and counseling in routine care for the user population and that may have been characterized as VCT services, thus influencing the coverage rates. The study attempted to control these effects by double-checking the information, which allowed extending the observed results to the set of services under the national VCT network.

\section{Resumo}

A rede nacional de Centros de Testagem e Aconselhamento (CTA) foi implantada no Brasil nos anos 1980 para promover, anônima e confidencialmente, o diagnóstico do HIV. Em função da população abrangida e das dimensões da epidemia local, o estudo avaliou a cobertura dessa rede, utilizando dados de questionário auto-aplicado e de bancos de informações do DATASUS, PNUD e Programa Nacional de DST e AIDS. Aplicou-se teste t para comparações de média e quiquadrado para proporções. Existem no Brasil 383 CTA, abrangendo 48,9\% da população e 69,2\% dos casos de AIDS. A rede está predominantemente implantada em regiões em que a epidemia é relevante, entretanto $85,3 \%$ das cidades com alta incidência não possuem CTA; ausência associada à menor estrutura de saúde e piores indicadores sociais. Observa-se desaceleração na expansão da rede, sendo um CTA implantado, em média, 16 anos após o primeiro caso de AIDS no município. $O$ número de testes realizados no SUS é 2,3 vezes maior em cidades com CTA. A abrangência da rede é reduzida, minimizando a contribuição desses serviços na oferta do diagnóstico do HIV no Brasil.

Testes Anônimos; Síndrome de Imunodeficiência Adquirida; Avaliação de Serviços de Saúde 


\section{Contributors}

A. Grangeiro participated in elaborating and implementing the study protocol, analytical plan, analysis, and writing of the article. M. M. Escuder participated in elaborating and implementing the study protocol, analytical plan, analysis, and writing of the article. M. A. Veras participated in elaborating the study protocol, analytical plan, and writing of the article. D. Barreira participated in implementing the study protocol and analytical plan and revising the article. D. Ferraz participated in elaborating and implementing the study protocol and revising the article. J. Kayano participated in the study protocol and revision of the article.

\section{References}

1. World Health Organization/Joint United Nations Programme on HIV/AIDS. Policy statement on HIV testing. http://www.who.int/rpc/research_eth ics/hivtestingpolicy_en_pdf.pdf (accessed on 15/ Aug/2007).

2. Basso CR. O Programa Nacional de DST/AIDS no SUS. In: Negri B, Viana ALA, organizadores. O Sistema Único de Saúde em dez anos de desafio. São Paulo: Sociedade Brasileira de Vigilância de Medicamentos/Centro de Estudos Augusto Leopoldo Ayrosa Galvão; 2002. p. 135-62.

3. Programa Nacional de DST e AIDS, Ministério da Saúde. Pesquisa de conhecimento, atitudes e práticas na população brasileira de 15 a 54 anos, 2004. Brasília: Ministério da Saúde; 2005.

4. World Health Organization/Joint United Nations Programme on HIV/AIDS/United Nations Children's Fund. Towards universal access: scaling up priority HIV/AIDS interventions in the health sector. Geneva: Joint United Nations Programme on HIV/AIDS; 2007.

\section{Acknowledgments}

Funding: Brazilian National STD/AIDS Program, Ministry of Health/United Nations Educational, Scientific, and Cultural Organization.
5. França-Junior I, Lopes F, Paiva V, Venturi G. Acesso ao teste anti-HIV no Brasil 2003: a pesquisa MS/ Ibope. http://www.aids.gov.br (accessed on 05/ Oct/2007).

6. Wolffenbuttel K. A organização tecnológica do Centro de Testagem e Aconselhamento (CTA): no enfrentamento da epidemia de DST/AIDS no Estado de São Paulo [Masters Thesis]. São Paulo: Faculdade de Medicina, Santa Casa de Misericórdia de São Paulo; 2006.

7. Minayo MCS, Souza ER, Assis SG, Cruz Neto O, Deslandes SF, Silva CMFP. Avaliação dos Centros de Orientação e Apoio Sorológico/CTA/COAS da Região Nordeste do Brasil. Cad Saúde Pública 1999; 15:355-67.

8. Souza SMB. Perfil epidemiológico da clientela de centros de testagem para o HIV e aconselhamento em Goiás - Brasil 1998 [Masters Thesis]. Goiânia: Universidade Federal de Goiás; 2000. 
9. Ferreira MPS, Silva CMFP, Gomes MCF, Silva SMB. Testagem sorológica para o HIV e a importância dos Centros de Testagem e Aconselhamento (CTA) - resultado de uma pesquisa no município do Rio de Janeiro. Ciênc Saúde Coletiva 2001; 6:481-90.

10. Cardoso AJC. Ensaios sobre a implantação nacional de um sistema de informação nos Centros de Testagem e Aconselhamento em DST e AIDS [PhD Dissertation]. Salvador: Universidade Federal da Bahia; 2004.

11. Lohn LG. Ação educativa em saúde: estudo de caso em Centro de Testagem e Aconselhamento [Masters Thesis]. Florianópolis: Universidade Federal de Santa Catarina; 2005.

12. Silva SMB. Centro de Testagem e Aconselhamento (CTA): caminhos e trilhas em construção [Masters Thesis]. Rio de Janeiro: Universidade Federal do Rio de Janeiro; 2004.

13. Araújo PJ. Estudo das características relacionadas à falha no retorno para aconselhamento pós-teste e entrega de resultado de HIV no Centro de Testagem e Aconselhamento Betinho [Masters Thesis]. São Paulo: Universidade de São Paulo; 2006.

14. Programa das Nações Unidas para o Desenvolvimento. Atlas do desenvolvimento humano. http: //www.pnud.org.br/atlas/ (accessed on 18/June/ 2007).

15. Rudy ET, Mahoney-Anderson PJ, Loughlin AM, Metsch LR, Kerndt PR, Gaul Z, et al. Perceptions of Human Immunodeficiency Virus (HIV) testing services among HIV positive persons not in medical care. Sex Transm Dis 2005; 32:207-13.

16. Souza Junior PRB, Szwarcwald CL, Barbosa Júnior A, Carvalho MF, Castilho EA. HIV infection during pregnancy: the Sentinel Surveillance Project, Brazil, 2002. Rev Saúde Pública 2004; 38:764-72.

17. Succi RCM; Grupo de Estudos da Sociedade Brasileira de Pediatria para Avaliar a Transmissão Materno-Infantil do HIV. Mother-to-child transmission of HIV in Brazil during the years 2000 and 2001: result of a multi-centric study. Cad Saúde Pública 2007; 23 Suppl 3:S379-89.

18. Segurado AC, Miranda SD, Latorre MRDO, Ayres JRCM, Marques HS, Buchalla C, et al. Evaluation of the care of women living with HIV/AIDS in Sao Paulo, Brazil. AIDS Patient Care STDS 2003; 17: 85-93.
19. Souza Junior PRB, Szwarcwald CL, Castilho EA. Delay in introducing antiretroviral therapy in patients infected by HIV in Brazil, 2003-2006. Clinics 2007; 62:579-84.

20. Fisher M. Late diagnosis of HIV infection: major consequences and missed opportunities. Infect Dis 2008; 21:1-3.

21. Fraser C, Hollingsworth D, Chapman R, Wolf F Hanage WP. Variation in HIV-1 set point viral load: epidemiological analysis and an evolutionary hypothesis. Proc Natl Acad Sci U S A 2007; 104:17441-6.

22. Barrio MA, Díez RG, Sanches JMH, Gomez O. Residual risk of transfusion transmitted viral infections in Spain, 1997-2002, and impact of nucleic acid testing. Euro Surveill 2005; 10:20-2.

23. Okie S. Fighting HIV - lesson from Brazil. N Engl J Med 2006; 354:1977-81.

24. Banco Mundial. Documento de avaliação de projeto sobre empréstimo mundial proposto no montante equivalente a US\$ 165 milhões ao Brasil para um segundo projeto de controle de AIDS e DST (Relatório no. 18338-BR). http://www.AIDS. gov.br/AIDS2_planejamento.htm (accessed on 30/ Mar/2001).

25. Bassichetto KC, Mesquita F, Zacaro C, Santos EA, Oliveira SM, Vera MASM, et al. Perfil epidemiológico dos usuários de um Centro de Testagem e Aconselhamento para DST/HIV da rede municipal de São Paulo, com sorologia positiva para HIV. Rev Bras Epidemiol 2004; 7:302-10.

26. Pechansky F, Kessler F, Diemen LV, Inciardi JA, Surrat H. Uso de substâncias, situações de risco e soroprevalência em indivíduos que buscavam testagem gratuita para HIV em Porto Alegre, Brasil. Rev Panam Salud Pública 2005; 18:249-55.

27. Almeida MRCB, Labronici LM. A trajetória silenciosa de pessoas portadoras do HIV contada pela história oral. Ciênc Saúde Coletiva 2007; 12:263-74.

28. Ferreira AD, Caiaffa WT, Bastos FI, Mingoti AS; Projeto AjUDE-Brasil II. Injecting drug users who are (un)aware of their HIV serostatus: findings from the multi-center study AjUDE-Brasil II. Cad Saúde Pública 2006; 22:815-26.

29. Ministério da Saúde. Avaliação da efetividade das ações de prevenção dirigidas às profissionais do sexo, em três regiões brasileiras. Brasília: Ministério da Saúde; 2004.

Submitted on 12/May/2008

Final version resubmitted on $06 /$ Oct $/ 2008$ Approved on 14/Nov/2008 